\title{
Economic Analysis of Marketing of Litchi (Litchi chinensis) in Himachal Pradesh
}

\author{
Ratika Kayastha*, Ravinder Sharma, Navneet Singh and Nitin Sharma
}

Department of Social Sciences, Dr. YS Parmar University of Horticulture \& Forestry, Nauni, Solan, Himachal Pradesh, India

*Corresponding author: rk11107139@gmail.com (ORCID ID: 0000- 0002-6137-4589)

Received: $12-05-2020$

Revised: 07-07-2020

Accepted: 27-08-2020

\begin{abstract}
The study was conducted in the Kangra district of Himachal Pradesh because of its significant contribution to the area and production of Litchi in the state. The current study was an attempt to find out marketing cost, market margins, price spread, and marketing efficiency of litchi growers in the selected area. The interview schedule was use to collect primary data from 60 growers of the Kangra district and from 5 wholesalers, 5 retailers and 5 pre-harvest contractors in the market. The findings indicated that most of the farmers sold their produce through the pre-harvest contractor. Also, three main marketing channels were found prevalent in the study area for the marketing of Litchi crops. The channel-C (Producer $\rightarrow$ Preharvest contractor $\rightarrow$ Wholesaler $\rightarrow$ Retailer $\rightarrow$ Consumer) was found to be the most preferred channel as 50.28 percent of the produce was traded through this marketing channel. The price spread found to be maximum in channel- $C$ which, was ₹ 3372.81. The marketing efficiency which was, estimated using Acharya's method, discovered highest in channel-A followed by channels D, B, and C, respectively.

Highlights

o Channel-C (Producer $\rightarrow$ Pre-harvest contractor $\rightarrow$ Wholesaler $\rightarrow$ Retailer $\rightarrow$ Consumer) found to be the most preferred channel in the study area, as 50.28 percent of the produce was traded through this marketing channel.
\end{abstract}

Keywords: Marketing channels, Marketing costs, Marketing efficiency, the Price spread

Litchi is a crucial fruit crop commercially grown in some states with tremendous export potential and plays a significant role in the economy. There has been an ever-increasing demand for litchi in domestic, and export markets. It is a native of China and introduced in India in $18^{\text {th }}$ century and then after that, it spread to other parts of the tropical and subtropical areas of the world. In India the area under Litchi is 92000 hectares with a production of 686000 MT. (NHB, 2018) The major Litchi growing states are Bihar, West Bengal, Uttrakhand, Jharkhand, Assam, Tripura, Orrisa, and Punjab. Bihar accounts for the major share $(70 \%)$ of the country's total litchi production. Himachal Pradesh possesses vast potential for growing subtropical and temperate fruits. There is potential for growing different varieties of fruits like mango, citrus, guava, and litchi. The low hills and submontane zone of Himachal Pradesh are suitable for Litchi cultivation; thus is a prominent fruit crop among orchardists. In Himachal, Litchi is confined mainly to the lower hills of district Kangra, with more than 80 percent of the total area under Litchi in the state. In Kangra, during 2017-2018, the total area under Litchi was 3303 hectares with the production of 3817 tonnes (Statistical Outline HP, 2018-19). Therefore in the process of creation of Litchi, marketing plays a vital role as the producers has to incur the production costs which are further determined by the producer's performance in the

\footnotetext{
How to cite this article: Kayastha, R., Sharma, R., Singh, N. and Sharma, N. (2020). Economic Analysis of Marketing of Litchi (Litchi chinensis) in Himachal Pradesh. Economic Affairs, 65(3): 343-348.

Source of Support: None; Conflict of Interest: None
} 
market along with the marketing efficiency of the intermediaries, which influence the returns to the growers. Therefore such studies are useful because the marketing of Litchi is a complicated activity due to its perishable nature. The present research focuses on the economics of marketing of Litchi in Himachal Pradesh to identify the marketing channels, analyzing the marketing costs, marketing margins, marketing efficiency, and price spread.

\section{MATERIALS AND METHODS}

The study was conducted in the Kangra district of Himachal Pradesh. This area was selected because of its significant contribution concerning to the area and production of Litchi in the state, thereby providing a medium of income generation to the growers. A Multistage random sampling technique was used to select the Litchi growers. At the first stage, 3 blocks namely, Bhawarna, Sulha, and Nagrota Bagwan were selected out of 15 blocks based on highest area under Litchi cultivation. In the second stage, a list of villages from each selected block was prepared, and two communities from each block selected randomly. The list of respondents was developed based on the area under Litchi cultivation, and ten growers from each community were selected randomly, thus forming a sample of 60 farmers. Further, the data were also collected from five wholesalers, five pre-harvest contractors and five retailers selected randomly from the Kangra District.

The study was based on both secondary and primary data. The secondary data were collected concerning to the area and production of litchi from the Agriculture Department and block development offices. The primary data was collected based on pre-testing schedule by adopting a personal interview method from the selected households in the study area as well as the market intermediaries for finding out the marketing costs, marketing margins, marketing efficiency, and price spread.

\section{Descriptive tools}

The marketing costs, marketing margins, and price spread were calculated by conventional analysis using averages and percentages.

\section{Marketing costs}

The total costs incurred on marketing by the farmers and the various intermediaries involved calculated as follows:

$$
C=C_{F}+C_{m}
$$

Where,

$$
\begin{aligned}
& C=\text { Total costs of marketing } \\
& C_{F}=\text { Costs paid by the farmers } \\
& C_{m}=\text { Costs incurred by middlemen, }
\end{aligned}
$$

\section{Marketing margins}

Marketing margin of middleman calculated as the difference between the total payments (marketing costs + purchase price) and receipts (sale price) of the middlemen as:

$$
A_{m i}=P_{R I}-\left(P_{p i}+C_{m i}\right)
$$

Where,

$$
\begin{aligned}
& A_{m i}=\text { Absolute margin of middlemen } \\
& P_{R I}=\text { Total value of receipts per unit (sale price) } \\
& P_{p i}=\text { Purchase value of goods per unit } \\
& C_{m i}=\text { Costs incurred on marketing per unit }
\end{aligned}
$$

\section{Price spread}

Generally, the economic efficiency of the marketing system is measured in terms of price spread. The smaller the price spread, the higher the effectiveness of the marketing system. Price spread refers to the difference between the price paid by the consumer and the price received by the producer.

\section{Producer's price}

The net price received by the orchardist was calculated as,

$$
P_{f}=P_{s}-P_{c}
$$

Where,

$P_{f}=$ Net price received by the producer

$P_{s}=$ Producer's selling price

$P_{c}=$ Marketing cost incurred by the producer' 


\section{Producer's share in consumer's rupee}

$$
P_{s}=\left(P_{f} / P_{r}\right) \times 100
$$

Where,

$P_{s}=$ Producer's Share in consumer's rupee

$P_{f}=$ Price received by farmer per unit

$P_{r}=$ Retail price per unit/ Consumer's purchase price.

\section{Analytical tools}

\section{Measurement of marketing efficiency}

The marketing efficiency of different channels was worked out by using the following Acharya's formula:

$$
M E=\frac{R P}{M C+M M}-1
$$

Where,

$$
\begin{aligned}
& M E=\text { Marketing efficiency } \\
& R P=\text { Retailer's price } \\
& M C=\text { Total marketing cost } \\
& M M=\text { Total marketing margins }
\end{aligned}
$$

\section{RESULTS AND DISCUSSION}

\section{Marketing channels}

Marketing of Litchi follows different channels before reaching the ultimate consumer. In the study area, four mains channels were identified, which are the following:

$$
\begin{aligned}
& \text { Channel -A Producer } \rightarrow \text { Consumer } \\
& \text { Channel -B Producer } \rightarrow \text { Wholesaler } \rightarrow \text { Retailer } \rightarrow
\end{aligned}
$$

Most of the farmers sold their produce through the pre-harvest contractor i.e., Channel-C. The total quantity marketed through this channel worked out to be 50.28 percent of the whole product the study area, whereas channel- A promises higher share of the producer' in the consumer's rupee. About 5.84 percent of the whole produce was marketed through this channel presented in Fig. 1, respectively.

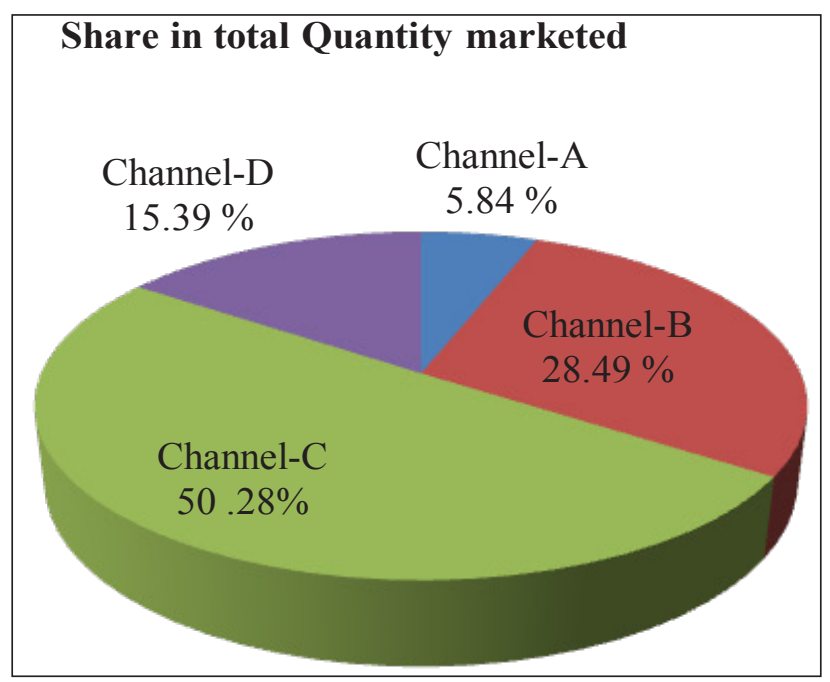

Fig. 1: Percent share of total quantity transacted through different marketing channels

\section{Marketing costs and margins by different functionaries in different channels}

In Channel-A, the total marketing cost incurred by the producer' worked out to be ₹ 183.95 per quintal. In Channel-B, producer' sold their produce to the wholesaler in the market, which was ₹ 251.83 per quintal, whereas in Channel-D, the total marketing cost incurred by the producer' worked out to be ₹ 243.85 per quintal presented in Table 1, respectively. The pre-harvest contractor was present in the marketing Channel-C. The total marketing cost incurred by the pre-harvest contractor in this marketing channel was ₹ 625.46 per quintal. In Channel-B and C the wholesaler spent $₹ 1191.93$ and 1193.97 per quintal in the marketing, out of which room rent, commission charges, and transportation cost accounted for $₹ 1037.43$ and $₹ 1039.48$ per quintal given in Table 2, respectively.

The price spread is presented in Table 2. The price spread found to be maximum in channel $\mathrm{C}$ ₹ 3372.81, followed by channels B, D, and A i.e., ₹ 2689.85 , ₹ 243.85 , and ₹ 183.95 , respectively. The producer's share in consumer rupee was maximum in channel A i.e. 97.27 percent and minimum in channel C i.e., 59.96 percent.

\section{Marketing efficiency of litchi among different channels}

In case of marketing channels, the marketing 
Table 1: Marketing costs and margins of different functionaries in the various marketing channels of Litchi (₹/Quintal)



Price spread among different channels. 
Table 2: Price spread of Litchi among the different marketing channels (₹/Quintal)

\begin{tabular}{lllll}
\hline Particulars & Channel A & Channel B & Channel C & Channel D \\
\hline Producer price (₹) & 6547.84 & 5635.26 & 5050.75 & 4172.17 \\
Consumer's price (₹) & 6731.79 & 8325.11 & 8423.56 & 4416.02 \\
Price spread & 183.95 & 2689.85 & 3372.81 & 243.85 \\
Producer's Share in consumer rupee & 97.27 & 67.69 & 59.96 & 94.48 \\
\hline
\end{tabular}

Table 3: Marketing efficiency of Litchi among the different marketing channels

\begin{tabular}{lllll}
\hline Particulars & Channel A & Channel B & Channel C & Channel D \\
\hline Marketing cost & 183.95 & 2089.85 & 2472.81 & 243.85 \\
Marketing efficiency & 35.60 & 2.10 & 1.50 & 17.11 \\
\hline
\end{tabular}

efficiency is concerned with the movement of goods from producer to consumer at the lowest possible cost consistent with the provision of services desired by the consumers. The marketing efficiency of various channels in the study area has been computed by using Acharya's method, was found to be highest in channel-A followed by channels $\mathrm{D}$, $\mathrm{B}$ and $\mathrm{C}$ respectively. Though channel $\mathrm{A}$ has been found to be most efficient but the volume transacted was very less $(5.84 \%)$.

\section{CONCLUSIONS}

Litchi occupies an important place in Horticulture landscape of Kangra District of Himachal Pradesh. Litchi is marketed through various channels. Channel -A Producer $\rightarrow$ Consumer was mainly preferred by the majority of the growers as this was the most convenient channel as it involved no intermediaries and has the highest producer' share in consumer's rupee which was 97.27 compared to other channels due to less marketing cost incurred in this channel. Hence, this marketing channel considered to be the best and most efficient amongst all the different marketing channels in the study area. The efficiency, which is an indicator of the overall performance of the marketing channels, found to be highest in channel-A followed by channels D, B, and C, respectively. Litchi is highly perishable fruit and its marketing should be done as quickly as possible. Poor transport conditions are major bottleneck in the marketing of the produce not only in Himachal Pradesh but in whole Asia. Marketing has a challenging task and key role to play in production, growth and development. Production technology can only sow the seeds and bring forth the fruit but marketing alone can pluck and deliver the output to the point where it is required after payment of fair prices to the farmers.

\section{REFERENCES}

Anonymous. 2017. Horticultural Data Base 2018, National Horticulture Board, New Delhi.

Anonymous. 2018. Statistical Outlines of Himachal Pradesh 2018-19. Directorate of Economics and Statistics Government of Himachal Pradesh.

Anchal, D. and Sharma, V.K. 2009. Price spread of litchi in Punjab. Indian Journal of Agricultural Marketing, 23: 147153.

Das, S.C. 2013. Studies of litchi cultivation and evaluation of different varieties and hybrids in Tripura. Asian Journal of Horticulture, 8: 520-525.

Gangwar, L.S., Singh, D. and Mandal, G. 2008. Production constraint and economics of peach in Punjab and Uttarakhand. Agricultural Economics Research Review, 21: 123-129.

Kaur, H.R. and Singh, I.P. 2010. Marketing of kinnow in Srinagar district of Rajasthan. Indian Journal of Agricultural Marketing, 24: 141-149.

Khalil, I., Idrees, M., Rabi, F., Rehman, S. and Bostan, N. 2014. An investigation into the problems of peach growers in district Swat. Journal of Agricultural and Biological Science, 9: 427-434.

Kumar, K. and Singh, H.L. 2010. Price spread of mango in Lucknow district. Indian Journal of Agricultural Marketing, 24: 50-57.

Negi, S. and Anand, N. 2015. Issues and challnges in the supply chain of fruit \& vegetables sector in India: A Review. International Journal of Managing Value and Supply Chains, 6: 47-62.

Prasher, R.S., Chandel, S. and Thakur, R. 2013. Economic appraisal of production and marketing of litchi in Himachal Pradesh. Indian Journal of Agriculture Marketing, 27: 1-13.

Sharma, N., Vaidya, M.K., Kayastha, R., Kumari, M. and Kumari, B. 2018. Economic analysis of production of 
$\underset{\text { AESSRA }}{\mathbb{U}_{\text {SRA }}}$ Kayastha et al.

white button mushroom (Agaricus bisporus) in Himachal Pradesh: A Case Study of Shimla district. International Journal of Chemical studies, 6(3): 97-100.

Singh, N., Sharma, R. and Kayastha, R. 2020. Economic analysis of pea (Pisum sativum) in Himachal Pradesh. Economic Affairs, 65(2): 01-05.
Verma, G., Mahajan, P.K. and Bharti. 2015. Economic appraisal of kinnow production and its marketing in the lower hills of Himachal Pradesh. International Journal of Farm Science, 5: 177-187. 